\title{
Amino acid profile in juvenile pikeperch (Sander lucioperca (L.)) - impact of supplementing feed with yeast extract
}

\author{
Sylwia Jarmołowicz, Zdzisław Zakęś
}

Received - 05 July 2013/Accepted - 27 November 2013. Published online: 30 June 2014; @Inland Fisheries Institute in Olsztyn, Poland Citation: Jarmołowicz S., Zakęś Z. 2014 - Amino acid profile in juvenile pikeperch (Sander lucioperca (L.)) - impact of supplementing feed with yeast extract - Arch. Pol. Fish. 22: 135-143.

\begin{abstract}
The European pikeperch, Sander lucioperca (L.) is a valuable species in aquaculture, and its nutritious meat is highly regarded by consumers. The contents of indispensable dietary amino acids (IDAA) in pikeperch fillets is higher than in other fish species and exceed the adult recommended daily allowance of them. Increasingly, the fish meal and soya protein components of fish feed are being replaced with protein from brewer's yeast, Saccharomyces cerevisiae. The aim of this study was to determine the fatty acid profiles of juvenile pikeperch fed feeds supplemented with yeast extract and to determine the IDAA requirements of this species using the ideal protein method. It was demonstrated that supplementing feed with yeast extract did not have a significant impact on nutrient accumulation in the fish. Pikeperch requirements for exogenous

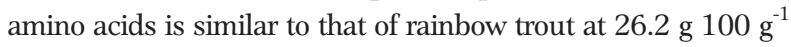
protein. Commercial feeds used in pikeperch culture contain sufficient quantities of essential amino acids.
\end{abstract}

Keywords: ideal protein, yeast, Saccharomyces cerevisiae, pikeperch, amino acid profile

\section{Introduction}

Global catches of pikeperch, Sander lucioperca (L.), in 2011 were nearly 17,300 tons, of which

\footnotetext{
S. Jarmołowicz [ $\left.\Xi^{\circ}\right]$, Z. Zakęś

Department of Aquaculture

Inland Fisheries Institute in Olsztyn, Poland

Oczapowskiego 10, 10-719 Olsztyn

e-mail: jarmolowicz@infish.com.pl
}

approximately 700 tons were produced by aquaculture (FAO 2012), but supplies of this species are still unable to meet increasing demand. In attempts to meet European demand for pikeperch, fish farms have been established in France, Holland, Switzerland, Denmark, Ireland, and other countries, where are developing new rearing techniques in recirculating aquaculture systems (RAS). Several new fish farms are set to begin operations in the near future in Croatia, Ireland, Sweden, Denmark, and other countries (Fontaine et al. 2008, Z. Zakęś, unpublished data). Pikeperch is valued by consumers for its excellent organoleptic and nutritional properties (Jankowska et al. 2003), and, in comparison to other fish species, pikeperch fillets also contain high levels of exogenous amino acids (Polak-Juszczak and Adamczyk 2009).

Limited supplies of fish meal and drastically rising prices for it are prompting the search for alternative sources of protein and the use of synthetic amino acids (AA) in feeds used in animal husbandry, and it is thought that diets should be formulated based on fully assimilable amino acids. One of the solutions currently being tested in aquaculture is yeast protein, Saccharomyces cerevisiae. The extract is obtained from inside the cells of these organisms, and, in addition to readily assimilable protein, it is rich in vitamins, nucleotides, and free amino acids. Brewer's yeast protein has been used as an alternative source 
of protein successfully with several fish species ( $\mathrm{Li}$ and Gatlin 2003, Craig and McLean 2005), and it has been demonstrated that feeding fish feed supplemented with $S$. cerevisiae extract has a positive impact on their condition (Jarmołowicz et al. 2012). There is also evidence that it is advantageous for the somatic growth of aquatic organisms, including fish (Staykov et al. 2007, Mamun et al. 2008, Nengas et al. 2009). The amino acid composition of yeast is similar to that of soya protein, and it is especially rich in glutamic acid and lysine.

In addition to their role as building blocks, amino acids are also utilized in numerous metabolic processes as the initial materials of purines, polyamines, catecholamines, thyroid hormone, serotonin, vitamins, and others ( $\mathrm{Li}$ et al. 2008). Amino acids are also used by fish to produce energy (Weltzien et al. 1999). It is thought that AA requirements are higher in the early stages of ontogeny (Aragão et al. 2004), and are likely dependent on the developmental rates of tissues and organs (Oikawa and Itazawa 1984). The indispensable dietary amino acids (IDAA) that are not synthesized in the body and must be consumed with food are of particular importance in animal nutrition. Fish are unable to synthesize the following ten amino acids: arginine, phenylalanine, histidine, isoleucine, leucine, lysine, methionine, threonine, tryptophan, and valine. The other amino acids that are synthesized by fish are known as endogenous or dispensable amino acids (DAA).

Except for publications dedicated to fatty acid profiles and vitamin and mineral contents in pikeperch bodies (Jankowska et al. 2003, Özyurt et al. 2009), the composition of the amino acid profile is practically unknown, and the nutritional requirements of pikeperch for IDAA have not yet been determined. To date, this has only been determined for a few species, e.g., channel catfish, Ictalurus punctatus (Raf.); carp, Cyprinus carpio L.; Japanese eel, Anguilla japonica Temminck \& Schlegel; tilapia, Oreochromis nilocitus (L.); and chinook salmon, Oncorhynchus tshawytscha (Walb.) (NRC 1993). IDAA requirements are determined using dose-based growth tests that are labor intensive and expensive (Akiyama et al. 1997). Recently, a relatively simple procedure known as the ideal protein method is being used with increasing frequency to determine the requirements of given species. This method postulates that to meet the requirements of IDAA the feed protein composition should be similar to that of the fish body (Miles and Chapman 2008). The ideal protein concept, which was introduced over fifty years ago in swine and poultry nutrition, can also be defined as the ideal ratio of nitrogen to exogenous amino acids for the optimal development of the animal (Boisen et al. 2000). Wilson and Poe (1985) and Wilson (1991) have applied this method successfully with fish. When the AA composition of the whole fish body is known, the requirements of IDAA are estimated taking into consideration the levels of lysine, which are determined with the growth test. Lysine is a reference amino acid since its only role is that of a building block, and it is not involved in other metabolic pathways in the body. Additionally, it is the amino acid that most limits the biological value of feed, and contents of it are usually the lowest. Significantly, determining this amino acid does not present any methodological problems (Miles and Chapman 2008). When the lysine requirement of a given species is unknown, many authors use values determined for other species from the same families (Akiyama et al. 1997). Namulawa et al. (2012) determined the amino acid requirement of the Nile perch, Lates niloticus (L.), using a conversion factor of $5.0 \mathrm{~g}$ lysine $100 \mathrm{~g}^{-1}$ protein. Kaushik (1998) also used this same factor with turbot, Scophthalmus maximus (L.). Among the Percidae, lysine requirements have only been established for yellow perch, Perca flavescens (Mitch.) (Twibell et al. 1998).

The aims of the present study were (I) to determine the proximal and amino acid compositions of whole bodies of juvenile pikeperch fed feeds supplemented with S. cerevisiae yeast extract, and (II) to determine the IDAA requirements of pikeperch using the ideal protein method. 


\section{Materials and methods}

\section{Rearing conditions and feeding}

The experiment was conducted at the Department of Aquaculture, Inland Fisheries Institute (IFI) in Olsztyn. Initially, the larvae were fed brine shrimp (Artemia sp.) and formulated feed (commercial trout starter). Following day 14 of rearing (larval age 18 days post hatch (DPH)), the fish were fed formulated feed exclusively (Szkudlarek and Zakęś 2007). Fish of a mean body weight of $37 \mathrm{~g}$ were stocked into 12 rotation tanks with volumes of $200 \mathrm{l}$ each in a RAS. The mean initial stocking density was $2.3 \mathrm{~kg} \mathrm{~m}^{-3}$ (35 fish $\operatorname{tank}^{-1}$ ). Water temperature, oxygen content, and total ammonia nitrogen (TAN $=\mathrm{NH}_{4}{ }^{+}-\mathrm{N}+\mathrm{NH}_{3}-\mathrm{N}$ ) and nitrite $\left(\mathrm{NO}_{2}-\mathrm{N}\right)$ were measured at the outflow of the rearing tanks and were as follows: $21.9 \pm 0.3^{\circ} \mathrm{C} ; 5.07$ $\pm 0.62 \mathrm{mg} \mathrm{O}_{2} \mathrm{l}^{-1} ; 0.177 \pm 0.098 \mathrm{mg} \mathrm{TAN} \mathrm{l}^{-1}$ and $0.015 \pm 0.004 \mathrm{NO}_{2}-\mathrm{N} \mathrm{mg} \mathrm{l}^{-1}$. The water $\mathrm{pH}$ range was 7.6-8.4, and light intensity at the water surface of the rearing tanks was 50-60 lx.

Commercial trout feed (Nutra 1.9; Nutreco, Holland) with a granulation size of $1.9 \mathrm{~mm}$ was supplemented with $S$. cerevisiae yeast extract $\left(\mathrm{NuPro}^{\circledR}\right.$,

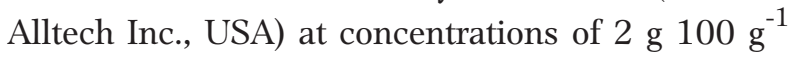

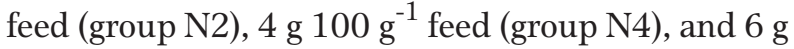
$100 \mathrm{~g}^{-1}$ feed (group N6) (Table 1). The extract portion was mixed with $6 \mathrm{ml}$ of distilled water and $100 \mathrm{~g}$ of the base feed was added and sealed with a vacuum pump (AGA Labor, Lublin, Poland). The prepared feed was dried for $24 \mathrm{~h}$ at room temperature. The control group (group C) comprised fish fed the base feed to which only water had been added. The feed contained approximately $50 \mathrm{~g}$ protein $100 \mathrm{~g}^{-1}$ feed and 16-17 g fat $100 \mathrm{~g}^{-1}$ feed (Table 1).

Four experimental feed groups of fish (C, N2, N4, N6), each in three replicates $(n=3)$, were reared for eight weeks. Feed was delivered by automatic band feeders (4305 FIAP; Fish Technic Gmbh, Ursensollen, Germany) for $18 \mathrm{~h} \mathrm{~d}^{-1}$ (10:00 - 04:00). The daily feed ration was from $1.3 \%$ of stocking biomass in the first two weeks of rearing to $1.0 \%$ in the last week of rearing.

\section{Analyses of proximate composition and amino acid profiles}

At the end of the experiment, the proximate composition and amino acid profile of whole pikeperch were determined. To do this, five individuals were selected at random from two tanks of each experimental feed group $(n=2)$. Before decapitation, the fish were anesthetized in an aqueous solution of etomidate (Propiscin, IFI Olsztyn). The whole fish samples from each tank were combined and analyzed together. The proximate composition and amino acid profile of the feeds were also analyzed (Table 1). Protein content was determined with the Kjeldahl method using a nitrogen to protein conversion coefficient of 6.25. Fat was determined with the Soxhlet method, and ash was determined by incinerating samples at a temperature of $550^{\circ} \mathrm{C}$ (AOAC 1975). The crude fiber in the feed was also determined (Tecator Fibertec System $M$ 1020). Amino acids were determined with an automatic Biochrom 20 plus analyzer (Biochrom Ltd., Cambridge, England) after the protein had been hydrolyzed in a nitrogen atmosphere in 6-mol $\mathrm{HCl}$ at a temperature of $110^{\circ} \mathrm{C}$ for $24 \mathrm{~h}$. The sulfur-containing amino acids cysteine and methionine were determined as cysteine acid and methionine sulfone after the samples had been oxidized with proformic acid. Tryptophan was hydrolyzed under alkaline conditions with a saturated barium hydroxide solution in a nitrogen atmosphere at a temperature of $110^{\circ} \mathrm{C}$ for $16 \mathrm{~h}$ (Knox et al. 1970, Hugli and Moore 1972).

\section{Data analyses}

The ratio of each essential amino acid (A) to the sum total of essential amino acids in the whole body of the fish (E) was calculated with the following formula: $\mathrm{A} / \mathrm{E}=$ (content of individual IDAA/Total IDAA) $\times$ 1000 (Arai 1981). The pikeperch requirements for individual amino acids (Rqmt) were estimated using the lysine level established for yellow perch $-4.0 \mathrm{~g}$ $100 \mathrm{~g}^{-1}$ protein (Twibell et al. 1998) and the formula proposed by Kaushik (1998): Rqmt $=($ Rqmt for 
Table 1

Proximate (g $100 \mathrm{~g}^{-1}$ dry weight) and amino acid (g $100 \mathrm{~g}^{-1}$ protein) compositions in control (C) and NuPro* experimental feeds (N2, N4, N6)

\begin{tabular}{|c|c|c|c|c|}
\hline & \multicolumn{4}{|c|}{ Feeds tested } \\
\hline & feed C & feed N2 & feed N4 & feed N6 \\
\hline Crude protein & 51.25 & 51.27 & 50.74 & 49.79 \\
\hline Crude fat & 17.44 & 16.99 & 16.52 & 15.99 \\
\hline Crude fiber & 1.90 & 1.91 & 1.87 & 1.82 \\
\hline Ash & 9.31 & 9.55 & 9.42 & 9.18 \\
\hline Nitrogen-free extracts (NFE) & 20.10 & 20.28 & 21.45 & 23.22 \\
\hline Gross energy (MJ kg ${ }^{-1}$ feed) & 22.52 & 22.38 & 22.27 & 22.13 \\
\hline Yeast extract & 0.0 & 2.0 & 4.0 & 6.0 \\
\hline \multicolumn{5}{|l|}{ Feed amino acid profile } \\
\hline Arginine (Arg) & 6.31 & 6.28 & 6.03 & 7.11 \\
\hline Histidine (His) & 4.11 & 3.99 & 4.77 & 4.37 \\
\hline Lysine (Lys) & 8.64 & 8.46 & 7.96 & 8.73 \\
\hline Tryptophan (Trp) & 0.88 & 0.91 & 0.96 & 0.93 \\
\hline Phenylalanine (Phe) & 5.54 & 5.49 & 5.42 & 5.83 \\
\hline Tyrosine $^{\S}$ (Tyr) & 5.04 & 4.74 & 5.45 & 5.80 \\
\hline Methionine (Met) & 3.41 & 3.06 & 3.05 & 3.04 \\
\hline Cysteine $^{\S}$ (Cys) & 3.27 & 2.63 & 2.93 & 2.68 \\
\hline Threonine (Thr) & 5.35 & 5.08 & 5.03 & 5.10 \\
\hline Leucine (Leu) & 9.47 & 9.10 & 8.97 & 9.50 \\
\hline Isoleucine (Ile) & 6.50 & 6.30 & 6.69 & 6.68 \\
\hline Valine (Val) & 6.69 & 6.61 & 6.55 & 6.99 \\
\hline Total IDAA ${ }^{\mathrm{a}}$ & 65.21 & 62.65 & 63.81 & 66.76 \\
\hline Alanine (Ala) & 6.53 & 6.40 & 6.35 & 6.56 \\
\hline Glycine (Gly) & 6.42 & 6.36 & 6.15 & 6.52 \\
\hline Glutamic acid (Glu) & 18.45 & 18.62 & 19.11 & 18.61 \\
\hline Asparagine (Asp) & 10.65 & 10.03 & 10.15 & 10.32 \\
\hline Proline (Pro) & 5.75 & 5.60 & 5.28 & 5.72 \\
\hline Serine (Ser) & 5.63 & 5.42 & 5.19 & 5.32 \\
\hline Total DAA ${ }^{\mathrm{b}}$ & 53.43 & 52.43 & 52.23 & 53.05 \\
\hline
\end{tabular}

${ }^{*}$ NuPro ${ }^{\circledR}$ extract: crude protein 46.5; crude fat 0.1; ash 5.7; NFE 39.5 (g $100 \mathrm{~g}^{-1}$ dry weight); IDAA: Arg 6.13; His 3.29; Lys 7.29; Trp 0.92; Phe 4.37; Tyr 4.30; Met 1.51; Cys 1.46; Thr 4.56; Leu 7.10; Ile 4.41; Val 5.98; DAA: Ala 8.34; Gly 5.35; Glu 12.90; Asp 8.58; Pro 4.80; Ser 5.23 (g $100 \mathrm{~g}^{-1}$ protein) (manufacturer's data)

$\S$ Tyrosine is synthesized from phenylalanine in cellular metabolism, while cysteine is synthesized from methionine

${ }^{\text {a } I D A A}$ - exogenous amino acids

${ }^{\mathrm{b}}$ DAA - endogenous amino acids

For further explanations see Materials and Methods section

lysine $\times \mathrm{A} / \mathrm{E}$ individual exogenous amino acids) $\times$ $\mathrm{A} / \mathrm{E}^{-1}$ for lysine. The nitrogen free extracts (NFE) of the feed were calculated with the following formula: $\mathrm{NFE}=100-$ (crude protein + crude fat + crude fiber + ash; Shearer 1994). The gross energy of the feed was determined using the following energy conversion factor: $24 \mathrm{~kJ} \mathrm{~g}^{-1}$ protein, $39 \mathrm{~kJ} \mathrm{~g}^{-1}$ fat, and $17 \mathrm{~kJ}$ $\mathrm{g}^{-1}$ NFE (Jobling 1994).
The results of the study were analyzed statistically with GraphPad Prism (Soft. Inc. La Jolla, CA, USA). Single-factor analysis of variance (ANOVA; P $\leq 0.5$ ) was applied, and when significant differences were confirmed among groups, Tukey's test was applied. 


\section{Results and discussion}

The feed did not impact pikeperch growth or condition. During the eight-week rearing period, the fish doubled their body weights, the mean of which ranged from $70 \mathrm{~g}$ (group N2) to $75 \mathrm{~g}$ (group C; P > 0.05) (Jarmołowicz et al. 2012). Feed supplemented with yeast extract did not have a significant impact on the proximate composition of the fish bodies or the amino acid profile $(\mathrm{P}>0.05$; Table 2$)$. An increase in the content of exogenous amino acids was noted in the group of fish fed the largest dose of yeast extract (group N6) as follows: threonine (14\% higher than in group C), valine (by 10\%), methionine (by $8 \%$ ), leucine (by 6\%), and isoleucine (by 5\%). Increases of $5 \%$ in comparison to group $\mathrm{C}$ were also noted in the content of the endogenous amino acids alanine, asparagine, and serine. No link was noted between the composition of the amino acid profile of the feed and the levels of individual AA in the whole fish body (Table 1 and 2).

Proteins in fish bodies are synthesized according to genetic information in the DNA, and the composition of the amino acid profile is independent of nutrition. However, differences in the amino acid profile composition might be apparent as the result of changes in free amino acids in tissues such as the muscles (Yamamoto et al. 2000). Supplementing feed with brewer's yeast extract does not have a significant impact on nutrient storage in pikeperch bodies. The base feed used in the present study contains a high quantity of protein, which is why the possible impact of the $S$. cerevisiae extract on the body of this species could be masked.

Table 2

Proximal (g $100 \mathrm{~g}^{-1}$ wet weight) and amino acid composition of pikeperch whole bodies ( $100 \mathrm{~g}^{-1}$ protein) fed increasingly large doses of yeast extract $S$. cerevisae (mean values $\pm \mathrm{SD} ; \mathrm{n}=2$; notation as in Table 1 )

\begin{tabular}{|c|c|c|c|c|}
\hline & \multicolumn{4}{|c|}{ Feeding treatment groups } \\
\hline & group C & group N2 & group N4 & group N6 \\
\hline Dry matter & $29.87 \pm 1.78$ & $28.63 \pm 0.58$ & $27.65 \pm 0.04$ & $28.53 \pm 0.14$ \\
\hline Crude protein & $17.71 \pm 0.11$ & $17.61 \pm 0.08$ & $17.18 \pm 0.06$ & $17.47 \pm 0.09$ \\
\hline Crude fat & $9.25 \pm 1.32$ & $7.96 \pm 0.35$ & $7.60 \pm 0.38$ & $8.14 \pm 0.36$ \\
\hline Crude ash & $3.43 \pm 0.18$ & $3.43 \pm 0.01$ & $3.17 \pm 0.05$ & $3.18 \pm 0.12$ \\
\hline \multicolumn{5}{|c|}{ Amino acid composition } \\
\hline Arginine & $6.83 \pm 0.24$ & $6.41 \pm 0.11$ & $7.17 \pm 0.23$ & $6.98 \pm 0.47$ \\
\hline Histidine & $4.53 \pm 0.64$ & $4.18 \pm 0.23$ & $4.13 \pm 0.07$ & $4.16 \pm 0.52$ \\
\hline Lysine & $9.45 \pm 0.40$ & $9.60 \pm 0.29$ & $9.56 \pm 0.41$ & $9.44 \pm 0.36$ \\
\hline Tryptophan & $0.93 \pm 0.04$ & $0.95 \pm 0.01$ & $0.91 \pm 0.06$ & $0.94 \pm 0.00$ \\
\hline Phenylalanine & $5.24 \pm 0.44$ & $4.94 \pm 0.43$ & $5.25 \pm 0.38$ & $5.30 \pm 0.95$ \\
\hline Tyrosine & $5.93 \pm 0.88$ & $5.26 \pm 0.29$ & $5.47 \pm 1.18$ & $5.69 \pm 0.02$ \\
\hline Methionine & $4.01 \pm 0.57$ & $3.86 \pm 0.71$ & $3.91 \pm 0.27$ & $4.34 \pm 0.42$ \\
\hline Cysteine & $2.86 \pm 0.54$ & $2.78 \pm 0.51$ & $2.60 \pm 0.23$ & $2.79 \pm 0.13$ \\
\hline Threonine & $4.94 \pm 0.07$ & $4.91 \pm 0.18$ & $5.60 \pm 0.62$ & $5.62 \pm 0.50$ \\
\hline Leucine & $7.97 \pm 0.42$ & $7.92 \pm 0.14$ & $7.95 \pm 0.80$ & $8.46 \pm 0.82$ \\
\hline Isoleucine & $5.47 \pm 0.36$ & $5.33 \pm 0.24$ & $5.81 \pm 0.56$ & $5.72 \pm 0.60$ \\
\hline Valine & $6.13 \pm 0.44$ & $5.99 \pm 0.21$ & $6.65 \pm 0.02$ & $6.72 \pm 1.03$ \\
\hline Total IDAA & 64.29 & 62.13 & 65.01 & 66.16 \\
\hline Alanine & $6.68 \pm 0.17$ & $6.34 \pm 0.05$ & $6.76 \pm 0.11$ & $7.04 \pm 0.53$ \\
\hline Glycine & $7.40 \pm 0.57$ & $7.08 \pm 0.35$ & $7.12 \pm 0.20$ & $7.34 \pm 0.22$ \\
\hline Glutamic acid & $14.62 \pm 0.57$ & $14.62 \pm 0.03$ & $14.06 \pm 0.56$ & $14.84 \pm 0.79$ \\
\hline Asparagine & $10.52 \pm 0.41$ & $10.44 \pm 0.06$ & $10.96 \pm 0.37$ & $11.05 \pm 0.54$ \\
\hline Proline & $4.52 \pm 0.60$ & $4.48 \pm 0.16$ & $4.45 \pm 0.38$ & $4.34 \pm 0.03$ \\
\hline Serine & $4.97 \pm 0.14$ & $4.88 \pm 0.07$ & $5.51 \pm 0.69$ & $5.54 \pm 0.25$ \\
\hline Total DAA & 48.71 & 47.84 & 48.86 & 50.15 \\
\hline
\end{tabular}

No statistically significant differences were noted among groups $(\mathrm{P}>0.05)$ 


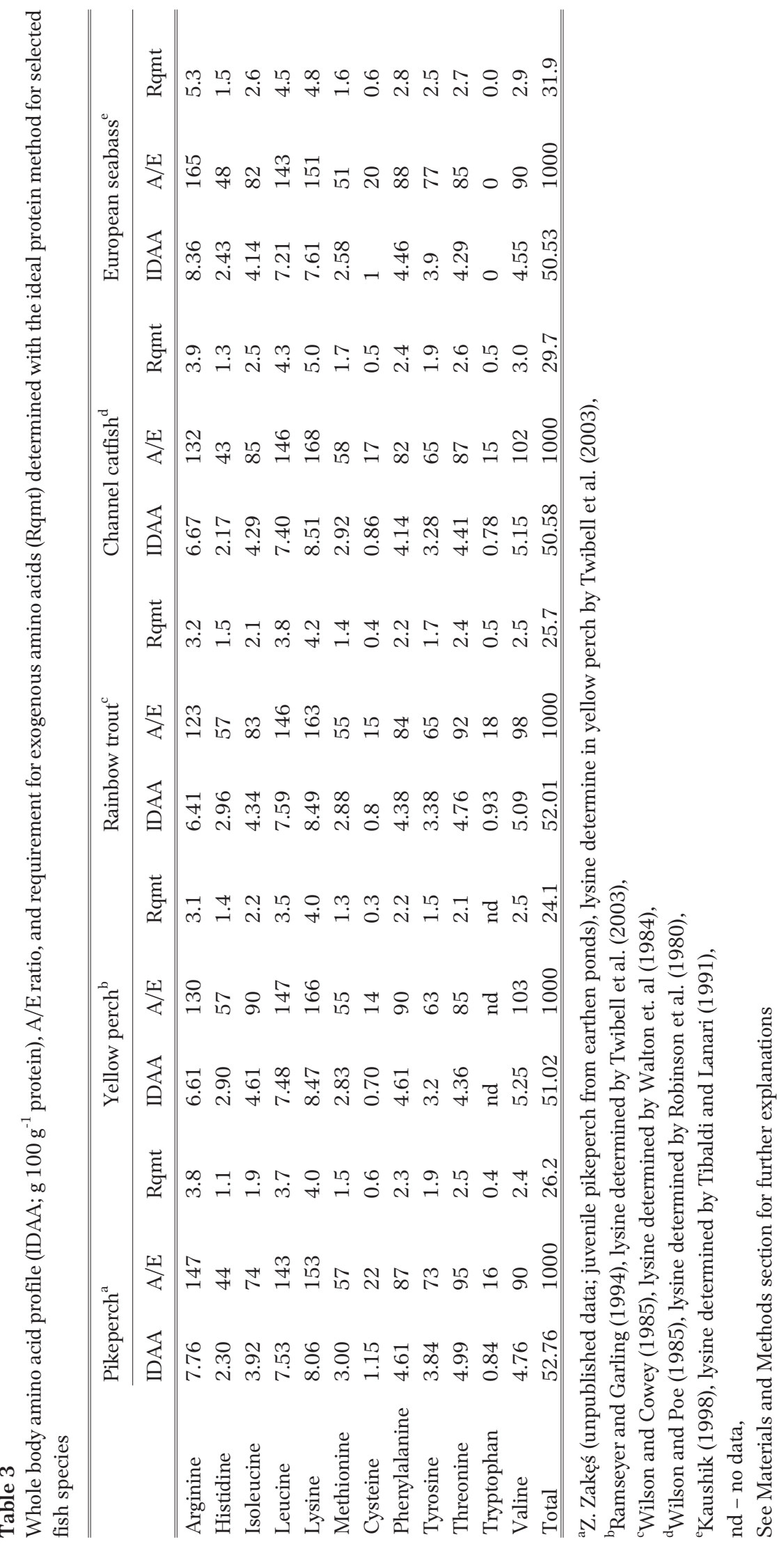


The amino acid profile of whole juvenile pikeperch (Z. Zakęś, unpublished data) differs just slightly from that of the yellow perch (Ramseyer and Garling 1994), rainbow trout, Oncorhynchus mykiss (Walb.), Wilson and Cowey 1985), channel catfish (Wilson and Poe 1985), and European seabass, Dicentrarchus labrax (L.), (Kaushik 1998). The level of IDAA in the bodies of these fish was 51-52 g 100 $\mathrm{g}^{-1}$ protein (Table 3). Although the composition of the amino acid profile is considered to be similar in all fish species (Wilson and Cowey 1985, Wilson 1989, Mohanty and Kaushik 1991), protein requirements differ depending on age, physiological condition, the environment inhabited, genotype, feeding factors, and other factors (Jobling 1994). Protein and amino acid requirements have not yet been determined for pikeperch, and quite substantial differences exist among the Percidae. It has been demonstrated that yellow perch require 21-27 g protein $100 \mathrm{~g}^{-1}$ feed, and European perch, Perca fluviatilis L., require 40-49 g protein $100 \mathrm{~g}^{-1}$ feed, while walleye, Sander vitreus (Mitch.), requires 42-51 g protein $100 \mathrm{~g}^{-1}$ feed (Brown and Barrows 2002). In percid aquaculture the fish are typically fed high-protein, high-energy, commercial feeds formulated for salmonids (Brown et al. 1996, Fontaine et al. 1996, Zakęś et al. 2001), and which comprise from 44 to 50 g protein $100 \mathrm{~g}^{-1}$ feed. It is thought that the high protein contents of the feed is a result of either its weak assimilability or a lack of knowledge of IDAA requirements (Miles and Chapman 2008).

Protein is the most expensive feed component and can account for 30 to $50 \%$ of a fish farming enterprise's operating costs. Throughout the world, the cost of protein depends largely on the cost of fish meal, which is even more expensive than high quality vegetable protein (Miles and Chapman 2008). This is why increasing attention is now being focused on the biological value of protein, and knowledge of its content in feed is insufficient. If the composition of the amino acid profile of fish bodies and the lysine level are known, then the ideal protein method can be used to estimate the requirements of the individual IDAAs. This is being used with increasing frequency to design diets for various fish species (see, among others, Brown 1995, Twibell et al. 2003, Namulawa et al. 2012). The initial value of lysine is usually determined using growth tests; with pikeperch the value used of $4.0 \mathrm{~g} 100 \mathrm{~g}^{-1}$ protein was determined earlier for yellow perch (Table 3; Twibell et al. 2003). Interestingly, Brown and Barrows (2002) report that this is one of the lowest reported levels of lysine determined for predatory fish. Generally, the level of

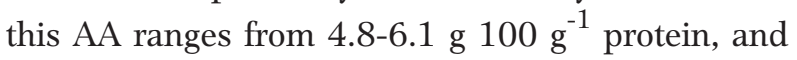
the higher value refers primarily to predatory fish (NRC 1993). The total pikeperch requirement for

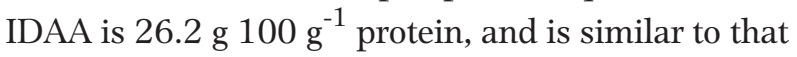

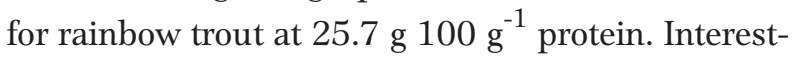
ingly, because of high lysine requirements, the levels of IDAA for channel catfish and European seabass are substantially higher (Table 3 ). It is generally thought that differences in determining lysine levels with growth tests can stem from differences among species, methodology, protein sources, and the experimental feeds used in experiments, and other factors (Tibaldi and Kaushik 2005). However, these values are substantially lower than the content of AA in feeds formulated with fish or soy meal or corn gluten which can contain approximately 50 g IDAA 100 $\mathrm{g}^{-1}$ protein (Akiyama et al. 1997). This is why commercial feeds used in pikeperch culture contain sufficient levels of exogenous amino acids even if the actual lysine requirement of this species were higher.

\section{Conclusions}

Supplementing feed with yeast extract at concentra-

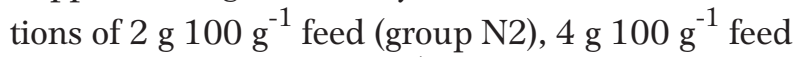

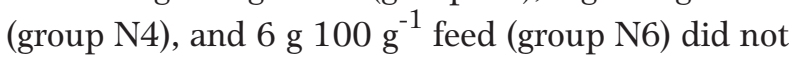
have a significant impact on nutrient accumulation in pikeperch bodies. The exogenous amino acid requirements of this species are similar to those of rain-

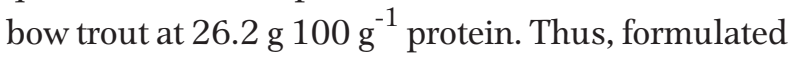
trout feed, which is used most often in pikeperch culture, fully meets the requirements of this species for essential amino acids. The estimated IDAA values derived based on the proximal composition of whole pikeperch could be useful in developing feeding tests 
and producing nutritionally complete feeds for this species. Continually growing interest in pikeperch aquaculture means that conducting growth experiments focusing on determining the requirements for exogenous amino acids (or even just lysine) are necessary.

Acknowledgements. The study was conducted within the framework of the statutory research program of the Inland Fisheries Institute in Olsztyn (No. S028).

Author contributions. S.J. and Z.Z. designed the research, S.J. performed the research, S.J. and Z.Z. analyzed the data, S.J. and Z.Z. wrote the paper.

\section{References}

Akiyama T., Oohara I., Yamamoto T. 1997 - Comparison of essential amino acid requirements with $\mathrm{A} / \mathrm{E}$ ratio among fish species - Fish. Sci. 63: 963-970.

AOAC 1975 - Official Methods of Analysis of the Association of Official Analytical Chemists - Washington, DC 20044.

Aragăo C., Conceiçăo L.E.C., Fyhn H.J., Dinis M.T. 2004 Estimated amino acid requirements during early ontogeny in fish with different life styles: gilthead seabream (Sparus aurata) and Senegalese sole (Solea senegalensis) - Aquaculture 242: 589-605.

Arai S. 1981 - A purified test diet for Coho salmon - Bull. Jap. Soc. Sci. Fish. 47: 547-550.

Boisen S., Hvelplund T., Weisbjerg M.R. 2000 - Ideal amino acid profiles as a basis for feed protein evaluation Livest. Prod. Sci. 64: 239-251.

Brown P.B. 1995 - Using whole-body amino acid patterns and quantitative requirements to rapidly develop diets for new species such as striped bass (Morone saxatilis) - J. Appl. Ichthyol. 11: 342-346.

Brown P.B., Barrows F.T. 2002 - Percids - In: Nutrient requirements and feeding of finfish for aquaculture (Eds) C.D. Webster, C.E. Lim, CABI Publishing, Wallingford, UK: 219-229.

Brown P.B., Dąbrowski K., Garling D.L. Jr. 1996 - Nutrition and feeding of yellow perch (Perca flavescens) - J. Appl. Ichthyol. 12:171-174.

Craig S.R., McLean E. 2005 - The organic movement: a role for $\mathrm{NuPro}{ }^{\circledR}$ as an alternative protein source - In: Nutritional Biotechnology in the Food and Feed Industry (Eds) K.A. Jacques, T.P. Lyons, Nottingham University Press, UK.

FAO 2012 - Cultured Aquatic Species Information Programme. Sander lucioperca. Cultured Aquatic
Species Information Programme. Text by Zakęś Z. In: FAO Fisheries and Aquaculture Department [online]. Rome, Italy. http://www.fao.org/.

Fontaine P., Kestemont P., Teletchea F., Wang N. 2008 Percid fish culture - from research to production Presses Universitaires de Namur, Namur, Belgium, 148 p.

Fontaine P., Tamazouzt L., Capdeville B. 1996 - Growth of the Eurasian perch (Perca fluviatilis L.) reared in floating cages and in water recirculated system: first results - J. Appl. Ichthyol. 12: 181-184.

Hugli T.E., Moore S. 1972 - Determination of the tryptophan content of proteins by ion exchange chromatography of alkaline hydrolysates - J. Biol. Chem. 247: 2828-2834.

Jankowska B., Zakęś Z., Żmijewski T., Szczepkowski M. 2003 - A comparison of selected quality features of the tissue and slaughter yield of wild and cultivated pikeperch Sander lucioperca (L.) - Eur. Food Res. Technol. 217: 401-405.

Jarmołowicz S., Zakęś Z., Siwicki A., Kowalska A., Hopko M., Głąbski E., Demska-Zakęś K., Partyka K. 2012 - Effects of brewer's yeast extract on growth performance and health of juvenile pikeperch Sander lucioperca (L.) Aquacult. Nutr. 18: 457-464.

Jobling M. 1994 - Fish bioenergetics - Chapman and Hall, London, UK.

Kaushik S.J. 1998 - Whole body amino acid composition of European seabass (Dicentrarchus labrax), gilthead seabream (Sparus aurata) and turbot (Psetta maxima) with an estimation of their IAA requirement profiles Aquat. Living Resour. 11: 355-358.

Knox R., Kohler G.O., Palter R., Walker H.G. 1970 - Determination of tryptophan in feeds - Analytical Biochem. 36: 136-143.

Li P., Gatlin III D.M. 2003 - Evaluation of brewers yeast (Saccharomyces cerevisiae) as a feed supplement for hybrid striped bass (Morone chrysops x M. saxatilis) Aquaculture 219: 681-692.

Li P., Mai K., Trushenski J., Wu G. 2008 - New developments in fish amino acid nutrition: towards functional and environmentally oriented aquafeeds - Amino Acids 37: 43-53.

Mamun M., King Ch., Rawlings R. 2008 - NuPro ${ }^{\circledR}$ improves body condition and grade uniformity of shrimp in Bangladesh - Alltech's 24th Annual Symposium, Lexington, Kentucky, USA.

Miles R.D., Chapman F.A. 2008 - The concept of ideal protein in formulation of aquaculture feeds - Department of Fisheries and Aquatic Sciences. University of Florida. USA, http://edis.ifas.ufl.edu/pdffiles/FA/FA14400.pdf.

Mohanty S.N., Kaushik S.J. 1991 - Whole body amino acid composition of Indian major carp and its significance Aquat. Living Resour. 4: 61-64. 
Namulawa V.T., Rutaisire J., Britz P.J. 2012 - Whole body and egg amino acid composition of Nile perch, Lates niloticus (Linnaeus, 1758) and prediction of its dietary essential amino acid requirements - Afr. J. Biotechnol. 11: 16615-16624.

National Research Council (NRC) 1993 - Nutrient Requirements of Fish - National Academy Press, Washington. D.C., USA.

Nengas I., Panayiotidou M., Morgan H. 2009 - Dietary supplementation with NuPro®: sea bass performance and immune response - Alltech's 25th Annual Symposium, Lexington, Kentucky, USA.

Oikawa S., Itazawa Y. 1984 - Relative growth of organs and parts of the carp, Cyprinus carpio, with special reference to the metabolism-size relationship - Copeia 1984: 800-803.

Özyurt G., Polat A., Loker G.B. 2009 - Vitamin and mineral content of pike perch (Sander lucioperca), common carp (Cyprinus carpio), and European catfish (Silurus glanis) Turk. J. Vet. Anim. Sci. 33: 351-356.

Polak-Juszczak L., Adamczyk M. 2009 - The quality and amino acid composition of fish protein from the Vistula Lagoon - Żywność. Nauka. Technologia. Jakość 3 (64): 75-83 (in Polish).

Ramseyer L.J., Garling D.L. Jr. 1994 - Amino acid composition of the ovaries, muscle and whole body of yellow perch - Prog. Fish-Cult. 56: 175-179.

Robinson E.H., Wilson R.P., Poe W.E. 1980 - Re-evaluation of the lysine requirement and lysine utilization by fingerling Chanel catfish - J. Nutr. 110: 2313-2316.

Shearer H.D., 1994 - Factors affecting the proximate composition of cultured fishes with emphasis on salmonids Aquaculture 119: 63-88.

Staykov Y., Spring P., Sweetmen J., Denev S.A. 2007 - The influence of 2 and $4 \%$ NuPro ${ }^{\circledR}$ on the growth performance of common carp (Cyprinus carpio L.), raised in net cages - Alltech's 23rd Annual Symposium, Lexington, Kentucky, USA.

Szkudlarek M., Zakęś Z. 2007 - Effect of stocking density on survival and growth performance of pikeperch, Sander lucioperca (L.), larvae under controlled conditions Aquacult. Int. 15: 67-81.
Tibaldi E., Kaushik S.J. 2005 - Amino acid requirements of Mediterranean fish species - Cahiers Options Méditerranéennes 63: 59-65.

Tibaldi E., Lanari D. 1991 - Optimal dietary lysine levels for growth and protein utilisation of fingerling seabass Dicentrarchus labrax - Aquaculture 95: 297-304.

Twibell R.G., Cartwright D.D., Wilson K.A., Brown P.B. 1998 - Dietary lysine requirement of juvenile yellow perch World Aquaculture '98, Las Vegas, NV, USA.

Twibell R.G., Griffi M.E., Martin B., Price J., Brown P.B. 2003 - Predicting dietary essential amino acid requirements for hybrid striped bass - Aquacult. Nutr. 9: 373-381.

Walton M.J., Cowey C.B., Adron J.W. 1984 - The effect of dietary lysine levels on growth and metabolism of rainbow trout (Salmo gairdneri) - Br. J. Nutr. 52: 115-122.

Weltzien F.A., Planas M., Cunha I., Evjen M.S., Fyhn H.J. 1999 - Free amino acid and protein contents of start-feeding larvae of turbot (Scophthalmus maximus) at three temperatures - Mar. Biol. 133: 327-336.

Wilson R.P. 1989 - Amino acids and proteins - In: Fish Nutrition (Ed) J.E. Halver, Academic Press, San Diego: 111-151.

Wilson R.P 1991 - Amino acid nutrition of fish: a new method of estimating requirement values - Proc. 12th U.S.Japan Symp. on Aquaculture Nutrition, Newport, Oregon 49-54.

Wilson R.P., Cowey C.B. 1985 - Amino acid composition of whole body tissue of rainbow trout and Atlantic salmonAquaculture 48: 373-376.

Wilson R.P., Poe W.E. 1985 - Relationship of whole body and egg essential amino acid patterns to amino acid requirement patterns in channel catfish, Ictalurus punctatus Comp. Biochem. Physiol. 80B: 385-388.

Yamamoto T., Unuma T., Akiyama T. 2000 - The influence of dietary protein and fat levels on tissue free amino acid levels of fingerling rainbow trout (Oncorhynchus mykiss) - Aquaculture 182: 353-372.

Zakęś Z., Szkudlarek M., Woźniak M., Karpiński A., Demska-Zakęś K. 2001 - Effect of dietary protein:fat ratios on metabolism, body composition and growth of juvenile pikeperch, Stizostedion lucioperca L. - Czech J. Anim. Sci. 46: 27-33. 